\title{
The effects of liraglutide on both hypereosinophilic insulin allergy and the characteristics of anti-insulin antibodies in type 2 diabetes mellitus: a case report
}

Hiroyuki Hirai ${ }^{1}$, Emi Ogata ${ }^{1}$, Nobuyuki Kikuchi ${ }^{2}$, Teruyuki Kohno ${ }^{1}$, Noritaka Machii ${ }^{1},{ }^{2}$ Koji Hasegawa ${ }^{1}$, Tsuyoshi Watanabe ${ }^{1}$ and Hiroaki Satoh ${ }^{1 *}$

\begin{abstract}
Background: Liraglutide is one of the glucagon-like peptide-1 analogs; there are only a few reports of liraglutide being used for the treatment of insulin allergy. Furthermore, anti-insulin immunoglobulin $\mathrm{G}$ antibodies are occasionally detected in patients with diabetes. Hence, we report a case in which switching to liraglutide therapy ameliorated both the symptoms of insulin allergy with hypereosinophilia and the characteristics of insulin antibodies in a patient with type 2 diabetes mellitus.

Case presentation: We present the case of a 70-year-old Japanese man with type 2 diabetes who developed insulin allergy with hypereosinophilia. Anti-insulin antibodies, high glycated hemoglobin levels (approximately 12 $\%)$, and high serum insulin levels were detected. Because a change in his insulin treatment was inefficient, treatment with liraglutide to protect residual insulin secretion was started, resulting in improvements in his insulin allergy, serum glycated hemoglobin, insulin, and eosinophil levels. Scatchard plots revealed decreased binding capacity and increased affinity constant for high affinity sites of anti-insulin antibodies.
\end{abstract}

Conclusions: Liraglutide might be useful for treating insulin allergy and anti-insulin antibodies in patients with type 2 diabetes.

Keywords: Liraglutide, Insulin allergy, Human insulin-specific immunoglobulin E, Hypereosinophilia, Anti-insulin immunoglobulin $\mathrm{G}$ antibodies

\section{Background}

Insulin allergy is an important adverse effect of insulin treatment in patients with diabetes. Ghazavi and Johnston recently reported that the prevalence of allergic reactions to insulin products is approximately $2 \%$ at present [1]. Although the frequency of insulin allergy is low, the symptoms vary, ranging from local injection site reactions to complete anaphylactic reactions [2,3]. Given that anaphylactic reactions are occasionally life-threatening, clinicians must act quickly and appropriately when allergy is suspected.

\footnotetext{
* Correspondence: hiroakis-tky@umin.ac.jp

${ }^{1}$ Department of Diabetology, Endocrinology, and Metabolism, Fukushima

Medical University, Fukushima 960-1295, Japan

Full list of author information is available at the end of the article
}

Glucagon-like peptide-1 (GLP-1) analogs have recently been introduced worldwide as a therapeutic option for the treatment of type 2 diabetes. Liraglutide is one such analog that improves blood glucose control by directly affecting both insulin and glucagon secretion in the pancreas [4]. However, there are only a few reports of liraglutide being used for the treatment of insulin allergy, and its effectiveness remains to be completely elucidated in this context $[5,6]$. Furthermore, anti-insulin immunoglobulin G (IgG) antibodies $[5,7,8]$ and anti-insulin receptor antibodies $[5,9]$ are occasionally detected in patients with diabetes who have brittle glycemic control or severe insulin resistance. The effectiveness of liraglutide remains unclear in these cases. 
We report a case in which switching to liraglutide therapy ameliorated both the symptoms of insulin allergy with hypereosinophilia and the characteristics of insulin antibodies in patients with type 2 diabetes mellitus.

\section{Case presentation}

\section{History leading to admission}

Our patient is a 70-year-old Japanese man with diabetes. He was admitted to our hospital 4.5 years ago for further investigation and treatment of recent-onset insulin allergy. He had a 30-year history of type 2 diabetes mellitus and an approximately 6-year history of insulin injection administration, with an average glycated hemoglobin (HbA1c) level of $7.0 \%$. He reported a past history of myocardial infarction, hypertension, and dyslipidemia and had undergone coronary artery bypass grafting at 68 years. During that surgery, intravenous protamine sulfate was administrated, which induced anaphylaxis.

At that time, 4.5 years prior to the current presentation, he was receiving $100 \mathrm{mg} /$ day aspirin, $100 \mathrm{mg} /$ day clopidogrel, $100 \mathrm{mg} /$ day imidapril, $20 \mathrm{mg} /$ day isosorbide mononitrate, $5 \mathrm{mg} /$ day nicorandil, and $10 \mathrm{mg} /$ day pravastatin, and these had been stable for more than 3 years. In addition, he was being treated with $20 \mathrm{U} /$ day insulin lispro and $8 \mathrm{U} /$ day insulin glargine, which had also been unchanged for approximately 3 years. Finally, he had been receiving $0.9 \mathrm{mg} /$ day voglibose to supplement his insulin therapy for approximately 5 years.

Approximately 5 months before his current presentation, he reported that he had started to develop wheals with redness and itching at the injection site, which occurred immediately after injecting insulin. Of note, these symptoms only occurred following the use of insulin lispro and not after insulin glargine. Over the subsequent months, part of the surface of the wheals had hardened and further investigation was performed. Two months before his current admission, blood samples were taken that revealed high serum levels of human insulinspecific immunoglobulin E (IgE; $4.21 \mathrm{U} / \mathrm{mL}$; normal range $<0.35 \mathrm{U} / \mathrm{mL}$ ), hypereosinophilia (total white blood cell count, $6000 / \mu \mathrm{L}$; total eosinophil granulocyte count, 780; percentage, $13 \%$ ), and a high level of total IgE (403 $\mathrm{IU} / \mathrm{mL}$; normal range $<173 \mathrm{IU} / \mathrm{mL}$ ). A pathology sample was taken 2 months before his admission, which revealed eosinophilic infiltration in the hardened part of the injection site (Fig. 1). Therefore, just before admission, he was diagnosed with insulin allergy and was switched from insulin lispro plus glargine to insulin aspart plus glargine.

\section{Admission for further investigation}

He was admitted to our hospital for treatment of his poor glycemic control and to evaluate his residual ability of insulin secretion. On admission, his physical examination

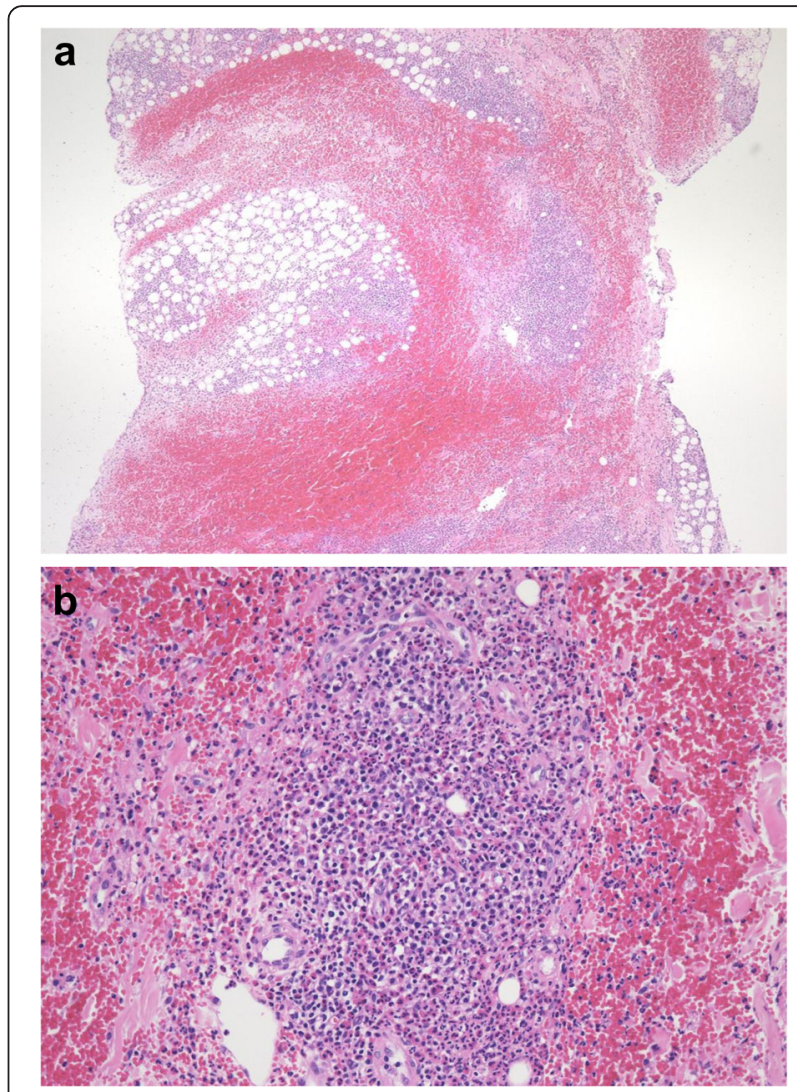

Fig. 1 Pathological findings of insulin injection site. Specimen obtained from the injection site of a 70-year-old man with diabetes. Hematoxylin-eosin staining showing predominant infiltration of eosinophils and the simultaneous infiltration of lymphocytic cells in the subcutaneous tissue. a Low-power micrograph 40x. b High-power micrograph 200x

was largely unremarkable (height, $157.1 \mathrm{~cm}$; body weight, $53.0 \mathrm{~kg}$; body mass index, $21.5 \mathrm{~kg} / \mathrm{m}^{2}$; body temperature, $36.5{ }^{\circ} \mathrm{C}$; blood pressure, $104 / 62 \mathrm{mmHg}$; and pulse, 75 beats/minute, regular), although there was induration with slight redness of his abdomen. His laboratory data at that time are shown in Table 1. Of note, his fasting plasma glucose level was $346 \mathrm{mg} / \mathrm{dL}$, and his HbA1c level was 12.3 $\%$. In addition, we detected high serum insulin, antiinsulin IgG antibody, and anti-insulin receptor antibody levels. Although there were no further symptoms of local allergy (wheals, redness, and itching) after injecting with insulin aspart, his postprandial hyperglycemia continued at approximately $350 \mathrm{mg} / \mathrm{dL}$. Therefore, he was switched to insulin glulisine (24 U/day) plus glargine (22 U/day) after admission. On day 17 of admission, his 24-hour blood glucose profile was $88,241,241,295,297$, and $292 \mathrm{mg} / \mathrm{dL}$ at 7:30 a.m., 10:00 a.m., 11:30 a.m., 2:00 p.m., 5:30 p.m., and 8:00 p.m., respectively, with an energy intake of $1600 \mathrm{kcal}$. On days 18 and 19, his urinary excretion of C-peptide was 42.8 to $51.5 \mu \mathrm{g} /$ day (normal range 40 to $100 \mu \mathrm{g} /$ day). On day 19 , a glucagon stimulation test was performed, and his 
Table 1 Laboratory data on admission

\begin{tabular}{|c|c|c|c|c|c|}
\hline Parameter & Result (normal range) & Unit & Parameter & Result (normal range) & Unit \\
\hline WBC & $5400(2800-8800)$ & $/ \mu \mathrm{L}$ & $\gamma G T P$ & $32(10-47)$ & $\mathrm{IU} / \mathrm{L}$ \\
\hline Neutrophil & $60(32-79)$ & $\%$ & Ch-E & $378(214-466)$ & IU/L \\
\hline Eosinophil & $15(0-6)$ & $\%$ & T-Bil & $0.9(0.2-1.2)$ & $\mathrm{mg} / \mathrm{dL}$ \\
\hline Lymphocyte & $16(18-59)$ & $\%$ & $\mathrm{Na}$ & $138(138-146)$ & $\mathrm{mEq} / \mathrm{L}$ \\
\hline Monocyte & $7(0-8)$ & $\%$ & K & $4.9(3.6-4.9)$ & $\mathrm{mEq} / \mathrm{L}$ \\
\hline Basophil & $2(0-2)$ & $\%$ & $\mathrm{Cl}$ & 99 (99-109) & $\mathrm{mEq} / \mathrm{L}$ \\
\hline RBC & $406 \times 10^{4}(366-478)$ & $/ \mu \mathrm{L}$ & BUN & $19(8-22)$ & $\mathrm{mg} / \mathrm{dL}$ \\
\hline $\mathrm{Hb}$ & $13.0(11.6-14)$ & $\mathrm{g} / \mathrm{dL}$ & Cre & $1.0(0.4-0.7)$ & $\mathrm{mg} / \mathrm{dL}$ \\
\hline Hct & $38.0(34.1-41.7)$ & $\%$ & UA & $4.7(2.3-7)$ & $\mathrm{mg} / \mathrm{dL}$ \\
\hline \multirow[t]{2}{*}{ Plt } & \multirow[t]{2}{*}{$15.2 \times 10^{4}(14.7-34.1)$} & \multirow[t]{2}{*}{$/ \mu \mathrm{L}$} & CK & $209 \quad(62-287)$ & $\mathrm{IU} / \mathrm{L}$ \\
\hline & & & AMY & $46(42-132)$ & $\mathrm{IU} / \mathrm{L}$ \\
\hline TP & $7.2(6.7-8.3)$ & $\mathrm{g} / \mathrm{dL}$ & CRP & $0.62 \quad(0-0.3)$ & $\mathrm{mg} / \mathrm{dL}$ \\
\hline Alb & $3.6(3.9-4.9)$ & $\mathrm{g} / \mathrm{dL}$ & $\mathrm{TC}$ & $149(150-219)$ & $\mathrm{mg} / \mathrm{dL}$ \\
\hline AST & $33(13-33)$ & $\mathrm{IU} / \mathrm{L}$ & TG & $70(30-150)$ & $\mathrm{mg} / \mathrm{dL}$ \\
\hline ALT & $28(6-27)$ & $\mathrm{IU} / \mathrm{L}$ & $\mathrm{HDL}-\mathrm{C}$ & $50(49-74)$ & $\mathrm{mg} / \mathrm{dL}$ \\
\hline FPG & 346 (70-109) & $\mathrm{mg} / \mathrm{dL}$ & ANA & Negative $(<40 \times)$ & \\
\hline F-INS & $9774(5-10)$ & $\mu \mathrm{IU} / \mathrm{mL}$ & $\mathrm{CH} 50$ & $<12(25-48)$ & $\mathrm{CH} 50 / \mathrm{mL}$ \\
\hline $\mathrm{F}-\mathrm{CPR}$ & $4.9(0.6-2.1)$ & $\mathrm{ng} / \mathrm{mL}$ & $\lg G$ & $1697(870-1700)$ & $\mathrm{mg} / \mathrm{dL}$ \\
\hline $\mathrm{HbA1c}$ & $12.3(4.7-6.2)$ & $\%$ & Anti-SS-A antibody & Negative & \\
\hline Glycoalbumin & $48.3(12.4-16.3)$ & $\%$ & Anti-SS-B antibody & Negative & \\
\hline GAD antibody & $0.3(0-5.0)$ & $\mathrm{U} / \mathrm{mL}$ & Anti-ds-DNA antibody & Negative & $\mathrm{IU} / \mathrm{mL}$ \\
\hline Human IgE & $5.57(0-0.34)$ & $\mathrm{U} / \mathrm{mL}$ & RF & $<3(<15)$ & $\mathrm{IU} / \mathrm{mL}$ \\
\hline IgG-anti-insulin antibodies & $14.5(<0.3)$ & $\%$ & & & \\
\hline Anti-insulin receptor antibodies & Positive & & Urine test & & \\
\hline $\mathrm{ACTH}$ & $11.6(7.2-63.3)$ & $\mathrm{pg} / \mathrm{mL}$ & U-Glucose & $(4+)$ & \\
\hline Cortisol & $17.9(6.2-19.4)$ & $\mu \mathrm{g} / \mathrm{dL}$ & U-Protein & Negative & \\
\hline TSH & $1.747(0.5-5.0)$ & $\mu \mathrm{IU} / \mathrm{mL}$ & U-Blood & Negative & \\
\hline FT4 & $2.11(0.9-1.7)$ & $\mathrm{ng} / \mathrm{dL}$ & U-Ketone & Negative & \\
\hline
\end{tabular}

ACTH adrenocorticotropic hormone, Alb albumin, ALT alanine aminotransferase, AMY amylase, ANA anti-nuclear antibody, Anti-ds-DNA anti-double-stranded DNA, anti-SS-A anti-Sjögren's syndrome A, anti-SS-B anti-Sjögren's syndrome B, AST aspartate aminotransferase, BUN blood urea nitrogen, Ch- $E$ cholinesterase, CK creatine, $C l$ chloride, Cre creatinine, CRP C-reactive protein, F-CPR fasting C-peptide, F-INS fasting insulin, FPG fasting plasma glucose, FT4 free thyroxine, GAD g lutamic acid decarboxylase, $\gamma$-GTP $\gamma$-glutamyl transpeptidase, $H b$ hemoglobin, $H b A 1 c$ glycated hemoglobin, $H c t$ hematocrit, $H D L-C$ high density lipoprotein cholesterol, IgE immunoglobulin E, IgG immunoglobulin $\mathrm{G}, K$ potassium, Na sodium, Plt platelets, $R B C$ red blood cells, $R F$ rheumatoid factor, $T$-Bil total bilirubin, TC total cholesterol, TG triglyceride, TP total protein, TSH thyroid-stimulating hormone, UA uric acid, WBC white blood cells

serum C-peptide response ranged from 3.2 to $3.6 \mathrm{ng} / \mathrm{mL}$ (Table 2). On day 22, although his high glucose levels persisted, he was discharged because we had confirmed his ability to secrete insulin. Although his hypereosinophilia was not resolved before his discharge, he had no further allergic symptoms (wheals, redness, and itchiness) at the injection site for glulisine, and the area of induration had almost disappeared.

\section{Progress since discharge and the introduction of liraglutide}

Figure 2 summarizes his clinical course before and after the introduction of liraglutide. After discharge, although glulisine and glargine were continued, his glycemic control worsened, with fasting and postprandial hyperglycemia levels of approximately 200 and $300 \mathrm{mg} / \mathrm{dL}$, respectively, and high serum insulin levels persisted (Fig. 2). Therefore, 2 months after his admission, we added $0.3 \mathrm{mg}$ liraglutide, discontinued the insulin glulisine, and added $2 \mathrm{mg} /$ day glimepiride and $500 \mathrm{mg} /$ day metformin to decrease his total insulin requirements. However, he also started to develop intermittent induration at the site of insulin glargine injection, and although there was no evidence of wheals or redness, his hypereosinophilia persisted. Based on these findings, we reduced the dose of glargine $(32 \rightarrow 22 \rightarrow 26 \rightarrow 10$ $\mathrm{U} /$ day $)$ and increased the dose of liraglutide $(0.3 \rightarrow 0.6 \rightarrow 0.9$ $\mathrm{mg} /$ day; Fig. 2). This was followed by improvements in his HbA1c, serum insulin, and eosinophil levels; therefore, we 
Table 2 An evaluation of the patient's insulin secretion ability

\begin{tabular}{lll}
\hline (a) Glucagon stimulation test & & \\
Time (minutes) & 0 & 6 \\
PG $(\mathrm{pg} / \mathrm{mL})$ & 112 & 122 \\
$\mathrm{CP}(\mathrm{ng} / \mathrm{mL})$ & 3.2 & 3.6 \\
(b) Urinary C-peptide excretion & & \\
Day 18 (after admission) & Day 19 & Normal range \\
$42.8 \mu \mathrm{g} /$ day & $51.5 \mu \mathrm{g} /$ day & $(40-100)$ \\
\hline
\end{tabular}

$C P$ C-peptide, $P G$ plasma glucose

decided to completely discontinue the insulin glargine after 3 months of the liraglutide treatment. On his new regimen of $0.9 \mathrm{mg} /$ day liraglutide in combination with oral antidiabetic agents, his HbAlc level was maintained at approximately $7.0 \%$. The induration had almost completely disappeared 1 month after the insulin injections were discontinued. In addition, his body weight decreased by $1.7 \mathrm{~kg}$ after 2 months of liraglutide treatment. Table 3 indicates his diabetes-related medical history.

\section{Supplemental investigation by Scatchard analysis}

We also elucidated the changes in the characteristics of anti-insulin IgG antibodies before and after treatment with liraglutide. Scatchard analysis of the anti-insulin IgG antibodies in our case indicated that there was a high binding capacity and a low affinity constant for the high affinity sites before liraglutide therapy (Fig. 3). After 1 year of treatment with liraglutide, the Scatchard plot indicated that the binding capacity decreased and the affinity constant for high affinity sites increased (Fig. 3). Of interest, the anti-insulin receptor antibodies had completely disappeared within 1 year after the injection of liraglutide.

\section{Discussion}

There are two important aspects to this case. First, we provide a rare description of insulin allergy associated with hypereosinophilia, anti-insulin IgG antibodies, and anti-insulin receptor antibodies in a patient with type 2 diabetes. Second, the marked efficacy of liraglutide suggests that it is useful in all patients with type 2 diabetes.

In our case, we believed that our patient's insulin allergy was predominantly a type 1 immediate reaction based on the fact that insulin lispro induced wheals, itching, and redness immediately after injection. Insulin allergy is typically classified into the following: type 1 , which is local and immediate; type 3 , which is related to autoimmune disease; and type 4 , which is a delayed-type reaction. Symptoms typically manifest within 15 minutes after insulin injection in type 1 reactions, approximately 6 hours after type 3 reactions, and 8 to 24 hours after type 4 reactions [2]. In our case, we confirmed that insulin lispro induced immediate symptoms but could not detect whether insulin aspart, glulisine, or glargine induced those reactions.

We did not perform either a skin prick test or an intradermal reaction test because of his past history of anaphylaxis. Out of concern for his safety, we substituted this with a non-invasive drug-induced lymphocyte stimulation test, which is normally considered best suited for delayed (type 4) reactions. Although this test was only positive for insulin glulisine, false-negatives have been detected in some cases, and we considered that insulin glargine was also associated with delayed-type allergy. This was because insulin glargine induced occasional induration and because its discontinuation resulted in improvement of both his induration and hypereosinophilia.

Based on the combination of these results, we concluded that our patient probably had a delayed-type allergic reaction that was complicated with a predominant immediate-type allergic reaction. Unfortunately, we did not obtain the list of additives in either the lispro or glargine, which could have been important given his history of protamine anaphylaxis. Further investigation of the cause of the allergic reactions could not be performed (for example, to other insulin preparations, including human neutral protamine Hagedorn, or the additives in the insulin types).

Previous reports of type 1 and type 4 allergic reactions to insulin indicate that hypereosinophilia does not necessarily occur. Therefore, the increase of eosinophilia in both local pathological findings and systemic peripheral blood is characteristic of this case. In general, although numerous eosinophils tend to be detected in local inflammation, such as allergy and parasitic infection, the complete role of eosinophils has not been elucidated [10]. For example, although hypereosinophilia has been observed in invasive parasitic infection, it has recently been reported to be partially defensive in vivo during such an infection [10]. In clinical cases of hypereosinophilia, clinicians must quickly and accurately diagnose the cause [11]. Potential causes in the differential diagnosis of this case included adrenal crisis, parasitic infection, and blood disease, but there was no evidence in support of these diagnoses. In addition, because hypereosinophilia simultaneously occurred with the observed clinical course of insulin allergy, we considered insulin allergy the more likely cause. This was consistent with the report by Nagai et al., who reported a case of immediate-type allergy against human insulin associated with marked eosinophilia in a patient with type 2 diabetes [12]. In that case, there was also the possibility of hypereosinophiliainduced renal dysfunction. Although there was no evidence of organ damage in this case, clinicians should remain vigilant for hypereosinophilic syndrome [11, 13] and be prepared to initiate appropriate therapy. Currently, 


\section{9}

Voglibose (mg)

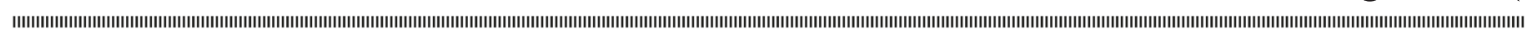

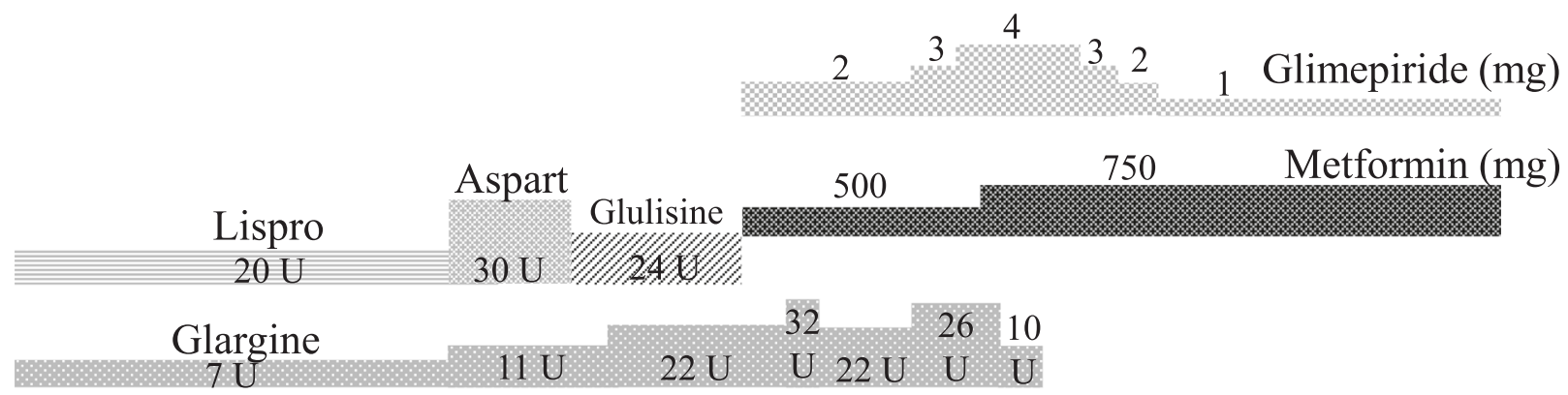

Liraglutide (mg)

0.30 .6

0.9

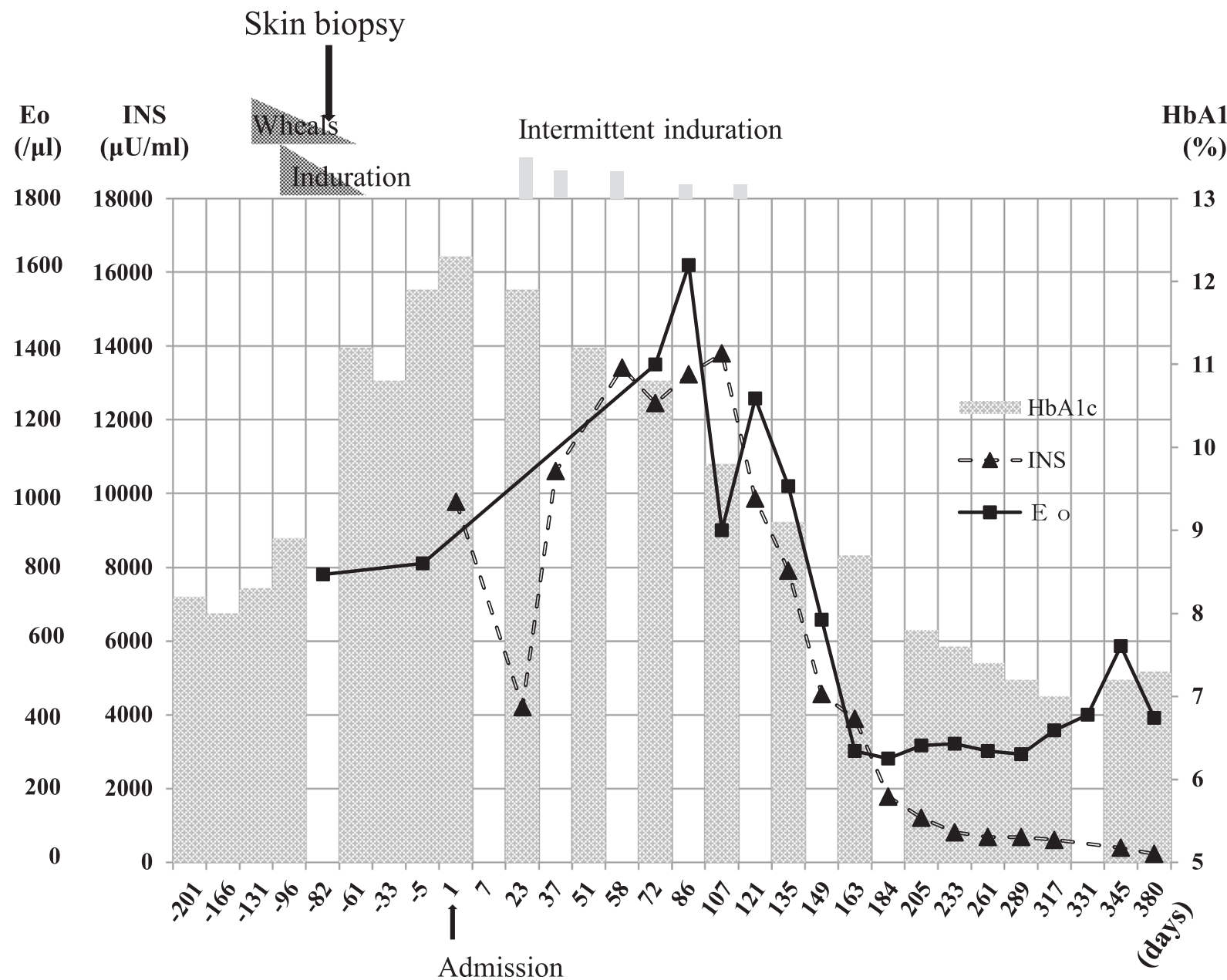

Fig. 2 Clinical course. A diagrammatic representation of the treatment and clinical course of a 70-year-old man with insulin allergy. He presented 5 months before his admission with wheals, redness, and itching immediately after insulin lispro injection that progressed to an area of induration. A skin biopsy and blood tests confirmed an allergy, and after trialing different insulin regimens, we eventually introduced $0.3 \mathrm{mg}$ liraglutide, discontinued the short-acting insulin, and added glimepiride and metformin. However, induration intermittently occurred after insulin glargine injections, so we eventually cross-tapered him off glargine and onto a liraglutide dose of $0.9 \mathrm{mg}$. Thereafter, his glycated hemoglobin, insulin, and eosinophil levels gradually improved. Eo eosinophil count, HbA1c glycated hemoglobin, INS insulin dose 
Table 3 Timeline

\begin{tabular}{|c|c|}
\hline Time & Diabetes-related medical history \\
\hline 1980s & Onset of type 2 diabetes mellitus \\
\hline 2009 & $\begin{array}{l}\text { Coronary artery bypass grafting was conducted, } \\
\text { anaphylaxis induced by intravenous protamine } \\
\text { sulfate administration }\end{array}$ \\
\hline May 2011 & Onset of allergy \\
\hline July 2011 & A skin biopsy and blood tests confirmed an allergy \\
\hline 24 October 2011 & Admission to our hospital \\
\hline 14 December 2011 & Liraglutide was additionally started \\
\hline 21 March 2012 & Insulin discontinued \\
\hline April 2012 & $\begin{array}{l}\text { The symptoms of insulin allergy almost } \\
\text { disappeared }\end{array}$ \\
\hline
\end{tabular}

treatment options for insulin allergy include switching to another insulin device [2], steroid therapy [2], continuous subcutaneous insulin infusion therapy [14], hyposensitization therapy [15], pancreas transplantation [16], and antiIgE therapy [17]. However, reports on the treatment of insulin allergy with hypereosinophilia are limited, and new options are needed. Therefore, we consider that liraglutide might be a breakthrough agent in the treatment of insulin allergy with hypereosinophilia in patients with type 2 diabetes. Indeed, a Medline search indicated that at the time of writing, we are the first to report the beneficial effects of liraglutide in this setting.

Treatment with liraglutide requires the residual ability to secrete insulin, but we do not know the appropriate range of insulin secretion that is necessary. Previously, Kozawa et al. reported that the cut-off value for predicting the efficacy of liraglutide was 1.1 for the C-peptide index, which was defined as (fasting C-peptide/glucose) $\times 100$, and $1.5 \mathrm{ng} / \mathrm{mL}$ for fasting C-peptide [18]. This index was also shown to be a predictive marker for the beta-cell area of the human pancreas $[18,19]$. Using a glucagon stimulation test, Usui et al. reported that a $\Delta C$-peptide value of $1.34 \mathrm{ng} / \mathrm{mL}$ was a useful cut-off point for switching from insulin to liraglutide without developing hyperglycemia [20]. In this case, although the fasting C-peptide level was high, the $\Delta C$-peptide in the glucagon stimulation test had a low value. Therefore, liraglutide alone could not inhibit postprandial hyperglycemia, and the antidiabetic drugs glimepiride, metformin, and voglibose were combined to achieve complete control. Moreover, the additional benefits of liraglutide include the prevention of body weight gain due to its appetite-suppressing and gastrointestinal peristaltic movement-suppressing effects. Liraglutide and other GLP-1 analogs have been reported to decrease body weight $[21,22]$. In our case, our patient's body weight decreased by only $1.7 \mathrm{~kg}$, but we could not administer liraglutide at a dose of more than $0.9 \mathrm{mg} /$ day. Worldwide, liraglutide is administered at a maximum dose of $1.8 \mathrm{mg} /$ day; however, Japan has approved that liraglutide is administered at a maximum dose of only $0.9 \mathrm{mg} /$ day.
In our case, it is possible that both the insulin allergy and the presence of anti-insulin IgG antibodies themselves aggravated our patient's glycemic control. Therefore, we tested his human leukocyte antigen-antigen $\mathrm{D}$ related (HLA-DR) type based on the report by Uchigata et al. that insulin autoimmune syndromes are strongly associated with HLA-DR4 [23]. We showed that his HLA-DR types were DR-9 and DR-15 and not DR-4; thus, we did not consider HLA-DR to be a potential causative factor for producing anti-insulin IgG antibodies. Instead, we concluded that the anti-insulin IgG antibodies resulted from the exogenous insulin injection; thus, we used liraglutide without insulin to decrease the amount of anti-insulin IgG antibodies and to avoid further production.

Moreover, Scatchard analysis of the anti-insulin IgG antibodies in our patient indicated that there was a high binding capacity and a low affinity constant for high affinity sites. At high affinity sites, Eguchi reported two important patterns of Scatchard analysis of anti-insulin IgG antibodies: (1) high (11.5 to 53.2$)$ binding capacity $\left(10^{-8} \mathrm{M}\right)$ and low $(0.04$ to 0.21$)$ affinity constant $\left(10^{8} \mathrm{M}^{-1}\right)$ in insulin autoimmune syndrome; and (2) low (0.12 to 1.1) binding capacity $\left(10^{-8} \mathrm{M}\right)$ and high (1.45 to 7.11$)$ affinity constant $\left(10^{8} \mathrm{M}^{-1}\right)$ in patients with diabetes requiring insulin therapy [24]. Therefore, the binding capacity and low affinity constant for high affinity sites are clinically important. Our patient had extremely high binding capacity and a low affinity constant compared with previous reports. In particular, his extremely high binding capacity was consistent with his high serum insulin levels.

After insulin therapy was discontinued and liraglutide was started, the characteristics of his anti-insulin IgG antibodies changed. Specifically, there was a notable decrease in the binding capacity and an increase in the affinity constant for high affinity sites (Fig. 3c). Hara et al. have reported that antibody-mediated insulin resistance was treated by ceasing insulin administration [25], whereas Tamura et al. reported that liraglutide ameliorated the anti-insulin IgG antibodies in a woman with type 2 diabetes receiving hemodialysis [26]. In our case, it remains unclear how liraglutide might have affected our patient's anti-insulin IgG antibodies; however, a recent report has suggested that GLP-1 receptor agonists interact with the immune system. In fact, Hadjiyanni et al. reported that GLP-1 receptor signaling selectively regulated murine lymphocyte proliferation and maintained peripheral regulatory T cells in vivo [27]. In humans, the effects of GLP-1 receptor agonists have been investigated in patients with psoriasis [28], but the detailed mechanism of action is unclear. Further reports are needed to improve our understanding of these agents.

Anti-insulin IgG antibodies have often been reported to induce hypoglycemia $[8,21,23,24]$. Unfortunately, we could not measure serum free insulin levels directly 
(A) Before liraglutide

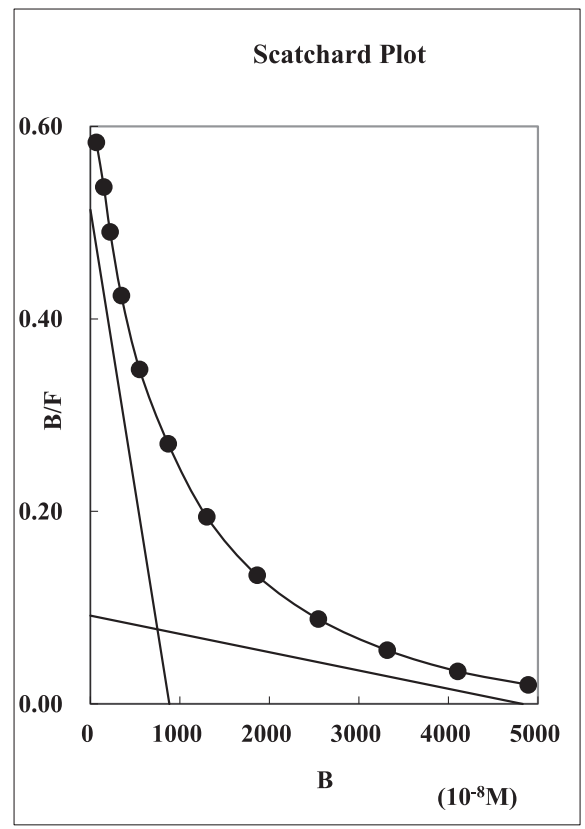

(C)
(B) After 1 year (approximately)

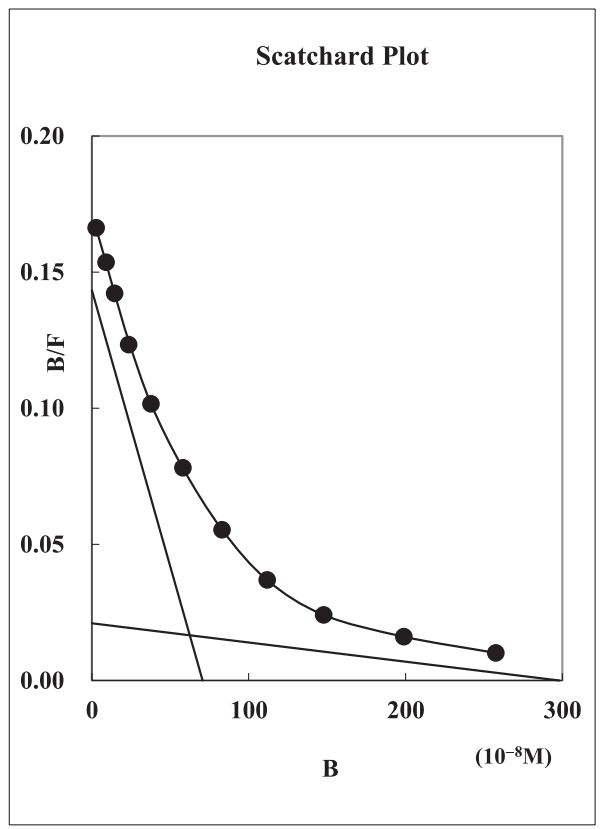

\section{High-affinity site}

Before liraglutide

\begin{tabular}{lccc}
\hline Binding capacity & $\left(\mathbf{1 0}^{-8} \mathbf{M}\right)$ & 882 & 70.6 \\
Affinity constant & $\left(\mathbf{1 0}^{\mathbf{8}} \mathbf{M}^{-\mathbf{1}}\right)$ & 0.000582 & 0.00203 \\
\hline
\end{tabular}

Fig. 3 Scatchard plot analysis showing changes in the characteristics of anti-insulin immunoglobulin $\mathrm{G}$ antibodies before and after treatment with liraglutide. a The Scatchard plot analysis before the treatment of liraglutide. The binding capacity $\left(10^{-8} \mathrm{M}\right)$ of $882\left(\mathrm{R}_{1}\right)$ and affinity constant $\left(10^{8} \mathrm{M}\right.$ ${ }^{-1}$ ) of $0.000582\left(K_{1}\right)$ for high affinity sites and the binding capacity $\left(10^{-8} \mathrm{M}\right)$ of $4830\left(\mathrm{R}_{2}\right)$ and affinity constant $\left(10^{8} \mathrm{M}^{-1}\right)$ of $0.0000190\left(\mathrm{~K}_{2}\right)$ for low affinity sites are shown. b The Scatchard plot analysis approximately 1 year after starting liraglutide. The binding capacity $\left(10^{-8} \mathrm{M}\right)$ of $70.6\left(\mathrm{R}_{1}\right)$ and affinity constant $\left(10^{8} \mathrm{M}^{-1}\right)$ of $0.00203\left(\mathrm{~K}_{1}\right)$ for high affinity sites and the binding capacity $\left(10^{-8} \mathrm{M}\right)$ of $298\left(\mathrm{R}_{2}\right)$ and affinity constant $\left(10^{8} \mathrm{M}^{-1}\right)$ of $0.0000704\left(K_{2}\right)$ for low affinity sites are shown. $\mathbf{c}$ It is notable, particularly for high affinity sites, that the binding capacity $\left(10^{-8} \mathrm{M}\right)$ has changed from 882 to $70.6\left(R_{1}\right)$, and that the affinity constant $\left(10^{8} \mathrm{M}^{-1}\right)$ has changed from 0.000582 to $0.00203\left(K_{1}\right)$. Therefore, liraglutide appeared to induce a decrease in the binding capacity and an increase in the affinity constant for high affinity sites of anti-insulin immunoglobulin $\mathrm{G}$ antibodies

and do not know whether the anti-insulin receptor antibodies really affected glucose metabolism. Although Kim et al. reported that anti-insulin receptor antibodies often coexist with anti-insulin IgG antibodies in Korean patients with insulin autoimmune syndrome [29], the clinical significance of this finding has been not determined. Acquired anti-insulin receptor antibodies induce severe insulin resistance, called "type B insulin resistance," which was first reported in 1976 [30]. However, we found no other symptoms or complications of type B insulin resistance, such as acanthosis nigricans or autoimmune disease (Table 1). In addition, the total insulin dose was smaller than that reported in previous studies on type B insulin resistance $[9,30]$. Therefore, we considered the possibility that the presence of anti-insulin receptor antibodies is a false positive in this case. It is also possible that the method of measurement led to a false positive result for anti-insulin receptor antibodies because we used the insulin binding inhibition method [31]. Perhaps the high insulin levels and high antiinsulin IgG antibodies levels had some unknown influence on the measured values.

\section{Conclusions}

In conclusion, our case suggests that liraglutide is a useful treatment for insulin allergy associated with 
hypereosinophilia and anti-insulin IgG antibodies in patients with type 2 diabetes. However, similar case reports are limited, and further reports are clearly needed.

\section{Abbreviations}

GLP-1, glucagon-like peptide-1; HbA1c, glycated hemoglobin; HLA-DR, human leukocyte antigen-antigen $D$ related; IgE, immunoglobulin $E_{;}$IgG, immunoglobulin G

\section{Acknowledgements}

We gratefully acknowledge our patient who allowed us to publish his case. This work was supported in part by a Grant-in-Aid Scientific Research from the Ministry of Education, Culture, Sports, Science, and Technology (HS). The contents are solely the responsibility of the authors and do not represent the official views of the funding institutions.

\section{Authors' contributions}

$\mathrm{HH}$ and $\mathrm{HS}$ were responsible for the original manuscript design and draft, and the acquisition of data. $\mathrm{HH}, \mathrm{HS}$, and TW were involved in drafting the manuscript. HS was involved in revision of the manuscript for important intellectual content. $\mathrm{HH}, \mathrm{EO}, \mathrm{NK}, \mathrm{TK}, \mathrm{NM}$, and $\mathrm{KH}$ were the physicians involved in patient management. All authors read and approved the final manuscript.

\section{Competing interests}

The authors declare that they have no competing interests.

\section{Consent for publication}

Written informed consent was obtained from the patient for publication of this case report and any accompanying images. A copy of the written consent is available for review by the Editor-in-Chief of this journal.

\section{Author details}

'Department of Diabetology, Endocrinology, and Metabolism, Fukushima Medical University, Fukushima 960-1295, Japan. ²Department of Dermatology, Fukushima Medical University, Fukushima 960-1295, Japan.

Received: 21 April 2016 Accepted: 6 July 2016

\section{Published online: 25 July 2016}

\section{References}

1. Ghazavi MK, Johnston GA. Insulin allergy. Clin Dermatol. 2011;29(3):300-5.

2. Heinzerling L, Raile K, Rochlitz H, Zuberbier T, Worm M. Insulin allergy: clinical manifestations and management strategies. Allergy. 2008;63(2):148-55.

3. Blanco C, Castillo R, Quiralte J, Delgado J, García I, de Pablos P, et al. Anaphylaxis to subcutaneous neutral protamine Hagedorn insulin with simultaneous sensitization to protamine and insulin. Allergy. 1996:51(6):421-4

4. Seino $Y$, Yabe D. Glucose-dependent insulinotropic polypeptide and glucagon-like peptide-1: Incretin actions beyond the pancreas. J Diabetes Investig. 2013;4(2):108-30.

5. Kawanami D, Ito T, Watanabe Y, Kinoshita J, Sakamoto M, Isaka T, et al. Successful control of a case of severe insulin allergy with liraglutide. J Diabetes Investig. 2013;4(1):94-6.

6. Fujishiro M, IzumidaY, Takemiya S, Kuwano Y, Takamoto I, Suzuki R, Yamauchi T, Ueki K, Kadowaki T. A case of insulin allergy successfully managed using multihexamer-forming insulin degludec combined with liraglutide. Diabet Med. 2015 Oct 20. doi:10.1111/dme.12998.

7. Berson SA, Yalow RS, Bauman A, Rothschild MA, Newerly K. Insulin-1 ${ }^{131}$ metabolism in human subjects: demonstration of insulin binding globulin in the circulation of insulin treated subjects. J Clin Invest. 1956;35(2):170-90.

8. lizuka K, Tomita R, Horikawa Y, Takeda J. A case of glycemic instability and insulin allergy due to anti-insulin antibodies in a patient with type 2 diabetes. Diabetol Int. 2012;3(4):233-8.

9. Yamada H, Asano T, Kusaka I, Kakei M, Ishikawa S. Type B insulin resistance syndrome with fasting hypoglycemia and postprandial hyperglycemia. Diabetol Int. 2015;6(2):144-48

10. Blanchard C, Marc E. Rothenberg biology of the eosinophil. Adv Immunol. 2009;101:81-121.

11. Roufosse F, Weller P. Practical approach to the patient with hypereosinophilia. J Allergy Clin Immunol. 2010;126(1):39-44.
12. Nagai Y, Mori T, Abe T, Nomura G. Immediate-type allergy against human insulin associated with marked eosinophilia in type 2 diabetic patient. Endocr J Jun. 2001;48(3):311-6.

13. Uriuhara A, Morita S, Kuroda S, Fumoto M, Araki S, Aoyama N, et al. Severe insulin-resistant diabetes mellitus associated with hypereosinophilic syndrome. Intern Med. 1994;33(10):632-6.

14. Nagai T, Nagai Y, Tomizawa T, Mori M. Immediate-type human insulin allergy successfully treated by continuous subcutaneous insulin infusion. Intern Med. 1997;36(8):575-8.

15. Matheu V, Perez E, Hernández M, Díaz E, Darias R, González A, et al. Insulin allergy and resistance successfully treated by desensitisation with aspart insulin. Clin Mol Allergy. 2005;23(3):16

16. Malaise J, Leonet J, Goffin E, Lefebvre C, Tennstedt D, Vandeleene B, et al. Pancreas transplantation for treatment of generalized allergy to human insulin in type 1 diabetes. Transplant Proc. 2005;37(6):2839.

17. Cavelti-Weder C, Muggli B, Keller C, Babians-Brunner A, Biason-Lauber A, Donath MY, et al. Successful use of omalizumab in an inadequately controlled type 2 diabetic patient with severe insulin allergy. Diabetes Care. 2012;35(6):e41.

18. Kozawa J, Inoue K, Iwamoto R, Kurashiki Y, Okauchi Y, Kashine S, et al. Liraglutide is effective in type 2 diabetic patients with sustained endogenous insulin-secreting capacity. J Diabetes Investig. 2012:3(3):294-7.

19. Meier JJ, Menge BA, Breuer TG, Müller CA, Tannapfel A, Uhl W, et al. Functional assessment of pancreatic $\beta$-cell area in humans. Diabetes. 2009; 58(7):1595-603.

20. Usui R, Yabe D, Kuwata H, Fujiwara S, Watanabe K, Hyo T, et al. Retrospective analysis of safety and efficacy of insulin-to-liraglutide switch in Japanese type 2 diabetes: A caution against inappropriate use in patients with reduced $\beta$-cell function. J Diabetes Investig. 2013;4(6):585-94.

21. Jendle J, Nauck MA, Matthews DR, Frid A, Hermansen $K$, Düring M, et al. LEAD-2 and LEAD-3 Study Groups: Weight loss with liraglutide, a once-daily human glucagon-like peptide-1 analogue for type 2 diabetes treatment as monotherapy or added to metformin, is primarily as a result of a reduction in fat tissue. Diabetes Obes Metab. 2009;11(12):1163-72.

22. Chen JH, Tang WH, Lee $\mathrm{CH}$. Effective weight loss after treatment with a glucagon-like peptide-1 receptor agonist in a morbidly obese and diabetic patient before bariatric surgeny: a case report. J Med Case Rep. 2014:8:304.

23. Uchigata Y, Kuwata S, Tokunaga K, Eguchi Y, Takayama-Hasumi S, Miyamoto $M$, et al. Strong association of insulin autoimmune syndrome with HLA-DR4. Lancet. 1992;339(8790):393-4.

24. Eguchi Y. Scatchard analysis of insulin autoantibodies in the insulin autoimmune syndrome (Japanese). J Tokyo Wom Med Univ. 1989:59:1296-305.

25. Hara K, Tobe K, Uchigata Y, Nakazono M, Yasuda K, Terauchi Y, et al. Antibody-mediated insulin resistance treated by cessation of insulin administration. Intern Med. 2000;39(2):143-5

26. Tamura Y, Kimbara Y, Funatsuki S, Mabuchi S, Kodera R, Yoshimoto A, et al. A case of insulin antibody-induced glucose instability in an elderly woman with type 2 diabetes on hemodialysis, successfully ameliorated with liraglutide. Diabetol Int. 2013;4(1):71-5

27. Hadjiyanni KA, Siminovitch JS, Drucker DJ. Glucagon-like peptide-1 receptor signaling selectively regulates murine lymphocyte proliferation and maintenance of peripheral regulatory T cells. Diabetologia. 2010;53(4):730-40

28. Al-Badri MR, Azar ST. Effect of glucagon-like peptide-1 receptor agonists in patients with psoriasis. Ther Adv Endocrinol Metab. 2014;5(2):34-8.

29. Kim SW, Won HK, Seok H, Lee BW, Jung CH, Lee WJ, et al. High prevalence of both anti-insulin and anti-insulin receptor antibodies in Korean patients with insulin autoimmune syndrome. Diabetes Res Clin Pract Nov. 2012;98(2):e12-5

30. Kahn CR, Flier JS, Bar RS, Archer JA, Gorden P, Martin MM, et al. The syndromes of insulin resistance and acanthosis nigricans - insulin-receptor disorders in man. N Engl J Med. 1976;294:739-45.

31. Filier JS, Kahn CR, Roth J, Bar RS. Antibodies that impair insulin receptor binding in an unusual diabetic syndrome with severe insulin resistance. Science. 1975:190:63-5. 